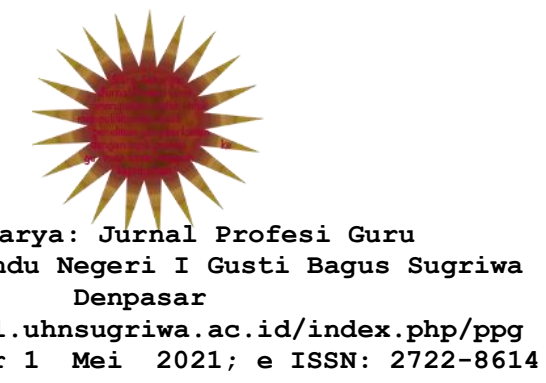

\title{
STRATEGI PEMBELAJARAN INKUIRI PADA PEMBELAJARAN DARING PENDIDIKAN AGAMA HINDU DAN BUDI PEKERTI
}

\author{
Ni Putu Sinta \\ Universitas Hindu Negeri I Gusti Bagus Sugriwa Denpasar \\ putusinta@gmail.com
}

Diterima 15 April 2021, direvisi 27 April 2021, diterbitkan 1 Mei 2021

\begin{abstract}
ABSTRAK
Kebjiakan pembelajaran Daring adalah salah satu dilematis yang dihadapi oleh peserta didik dan pendidik. Berbagai hambatan dan rintangan, tentunya membuat pembelajaran daring memiliki dampak positif dan negative. Di luar dampak tersebut, Pendidik musti beradaptasi dengan learning management system, dan menerapkan strategi pembelajaran yang tepat kepada peserta didik. Hal ini juga dialami oleh Guru Agama Hindu kelas X yang mengalami beberapa kesulitan ketika memberlakukan strategi pembelajaran yang tepat kepada siswanya. Guru kemudian menemukan strategi pembelajaran inkuiri yang dirasa membuat pembelajaran Agama Hindu dan Budi Pekerti lebih bermakna dan sesuai dengan prinsip $4 \mathrm{c}$ yaitu communication, collaboration, creative, dan critical thinking. Penyusunan artikel jurnal ini menggunakan metode penelitian kualitatif dengan studi kasus dengan teknik pengumpulan data berupa observasi dan studi dokumen. Teknik analisis data Miles dan Huberman digunakan dalam penyusunan artikel ini yaitu data reduction, data display, dan conclusion. Teori belajar konstruktivistik yang dikembangkan oleh Jean Piaget dan teori koneksionisme Thorndike digunakan sebagai pisau dan sudut pandang interaktif yang mengalir pada sub pembahasan. Penyusunan artikel ini bertujuan untuk mengetahui alasan, proses, serta implikasi dari penerapan strategi pembelajaran inkuiri pada pembelajaran Agama Hindu dan Budi Pekerti kelas X SMA Negeri 2 Denpasar.
\end{abstract}

\section{PENDAHULUAN}

Berawal dari pandemi covid 19, dunia pendidikan dirasa mengalami Trial and error yang terus diujicobakan dalam pembelajaran yang berbasis online ini. Peserta didik bahkan sampai bosan menghadapi dilema hampir satu setengah tahun jarang berkomunikasi tatap muka dengan keluarga sekolah. Karakteristik e-learning yang dipaparkan oleh Wahyuningsih dan Makmur (2017:12-14) yaitu tidak terbatas, fleksibel, kontrol pada peserta didik, multidimensional, sumber primer, dan dinamis. Terdapat tiga fungsi e-learning yaitu (1) sebagai supplement yaitu sebagai tambahan pembelajaran tatap muka. (2) sebagai complement yaitu untuk melengkapi pembelajaran tatap muka. (3) sebagai replacement digunakan sebagai pengganti pembelajaran tatap muka. 


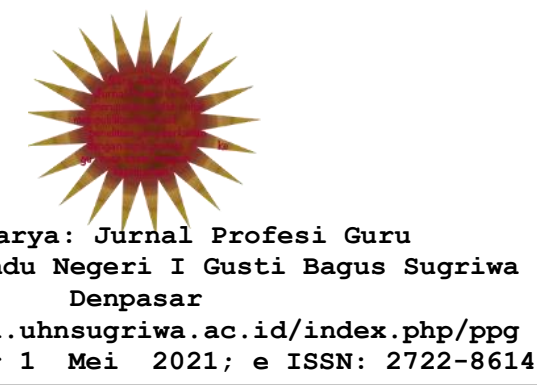

Salah satu sekolah negeri yang melangsungkan fungsi replacement tersebut adalah SMA Negeri 2 Denpasar. Pedomannya ada pada Surat Edaran Nomor :51/Satgas Covid19/Iii/2020 tentang Pelaksanaan Kebijakan Pendidikan dalam Masa Darurat Penyebaran Corona Virus Disease (Covid-19) di Provinsi Bali menyatakan bahwa kegiatan belajar mengajar dilaksanakan sebagai berikut: a.Belajar dari rumah melalui pembelajaran dalam jaringan (daring)/jarak jauh/online dilaksanakan untuk memberikan pengalaman belajar yang bermakna bagi siswa dan dapat difokuskan pada pendidikan kecakapan hidup, tanpa terbebani tuntutan menuntaskan seluruh capaian kurikulum untuk kenaikan kelas maupun kelulusan; b. Aktivitas dan tugas pembelajaran belajar dari rumah dapat bervariasi antar siswa, sesuai minat dan kondisi masing-masing, termasuk mempertimbangkan fasilitas akses belajar di rumah; c. Bukti atau produk aktivitas belajar dari rumah diberi umpan balik yang bersifat kualitatif dan berguna dari guru, tanpa diharuskan memberi skor/nilai kuantitatif.

Berdasarkan uraian surat edaran di atas, maka pembelajaran Agama Hindu dan Budi Pekerti juga diikutsertakan melaksanakan daring. Pembelajaran yang nota bene bertujuan untuk membentuk karakter peserta didik dengan dasar Ajaran Agama Hindu. Permasalahan utama yang dihadapi peserta didik khususnya kelas $X$ mengeluhkan beban psikis berupa tugas yang diberikan pada setiap mata pelajaran. Hal ini menunjukkan bahwa peserta didik perlu diberikan treatment yang tepat, agar kelas online terasa lebih kondusif, aktif, dan menyenangkan, bukan menambah beban psikologi siswa dengan memberikan tanggung jawab tugas yang tidak memperhatikan kondisi psikis dan mental peserta didik. Ini harus dimulai dari tahapan penyusunan, perencanaan, pelaksanaan, yang patut dikembangkan oleh pendidik dalam menyusun strategi pembelajaran yang serasi dengan pendekatan daring.

Strategi Pembelajaran menurut Ngalimun (2017:8), merupakan rencana tindakan (rangkaian kegiatan) termasuk penggunan metode dan pemanfaatan berbagai sumber daya atau kekuatan dalam pembelajaran. Strategi disusun untuk mencapai tujuan tertentu . Artinya arah dari semua keputusan penyusunan strategi adalah pencapaian tujuan. Sebelum menentukan strategi, perlu dirumuskan tujuan yang jelas, yang dapat diukur keberhasilannya, sebab tujuan adalah rohnya dalam implementasi suatu strategi. Senada dengan yang diungkapkan oleh Maswan dan Muslimin (2017: 264), strategi pembelajaran mempunyai pengertian suatu garis-garis besar haluan untuk bertindak dalam usaha mencapai sasaran yang telah ditentukan. Dihubungkan dengan belajar mengajar, strategi bisa diartikan sebagai pola-pola umum kegiatan guru dan anak didik dalam perwujudan kegiatan belajar mengajar untuk mencapai tujuan yang telah digariskan. Jika disimpulkan dari dua pendapat tersebut, maka strategi pembelajaran adalah rencana pembelajaran yang disusun menggunakan metode, teknik, dan cara tertentu yang digunakan oleh pendidik, untuk mencapai tujuan pembelajaran. Ngalimun (2017:13) juga menambahkan strategi yang diterapkan oleh guru akan tergantung pada pendekatan yang digunakan, sedangkan bagaimana menjalankan strategi itu, dapat diterapkan sebagai metode pembelajaran. Dalam upaya menjalankan metode pembelajaran, guru dapat menentukan teknik yang dianggap relevan dengan metode, dan penggunaan teknik itu setiap guru memiliki taktik yang mungkin berbeda antara guru yang satu dengan yang lain. 


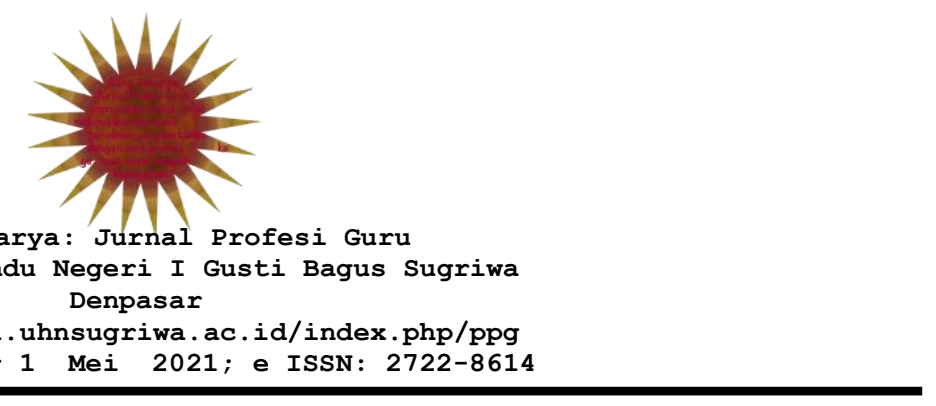

Strategi pembelajaran inkuiri menekankan kepada proses mencari dan menemukan. Peran siswa dalam strategi ini adalah mencari dan menemukan sendiri materi pelajaran, sedangkan guru berperan sebagai fasilitator dan pembimbing siswa untuk belajar. Walaupun masih ada kendala yang dihadapi baik teknis seperti sinyal, dan non teknis seperti peserta didik masih saja ada yang tidak fokus di dalam pembelajaran. Inilah yang membuat penyusun ingin menelisik lebih dalam alasan dibalik penggunaan strategi pembelajaran inkuri, proses penerapannya, kendala serta implikasi dari strategi tersebut. Strategi inilah yang dipergunakan oleh Guru Agama kelas X untuk melaksanakan pembelajaran Daring Pendidikan Agama Hindu, tentunya dalam proses penerapan tentu ada hambatan dan kendala.

Berdasarkan latar belakang tersebut, penyusun merumuskan masalah berupa (1) Mengapa dilaksanakan strategi pembelajaran inkuiri pada pembelajaran daring pendidikan agama Hindu dan Budi Pekerti kelas XSMA Negeri 2 Denpasar? ; (2) Bagaimanakah penerapan strategi pembelajaran inkuiri pada pembelajaran daring pendidikan agama Hindu dan Budi Pekerti kelas XSMA Negeri 2 Denpasar? ; (3) Bagaimanakah implikasi dari penerapan strategi pembelajaran inkuiri pada pembelajaran daring pendidikan agama Hindu dan Budi Pekerti kelas XSMA Negeri 2 Denpasar?

Tujuan umum dari penyusunan ini adalah untuk mengetahui penerapan strategi pembelajaran inkuiri pada pembelajaran Agama Hindu dan Budi Pekerti kelas X SMA Negeri 2 Denpasar. Tujuan khususnya adalah untuk mengetahui (1) alasan dilaksanakannya strategi pembelajaran inkuiri pada pembelajaran daring pendidikan agama Hindu dan Budi Pekerti kelas XSMA Negeri 2 Denpasar; (2) untuk mengetahui proses penerapan strategi pembelajaran inkuiri pada pembelajaran daring pendidikan agama Hindu dan Budi Pekerti kelas XSMA Negeri 2 Denpasar; (3) untuk mengetahui implikasi dari penerapan strategi pembelajaran inkuiri pada pembelajaran daring pendidikan agama Hindu dan Budi Pekerti kelas XSMA Negeri 2 Denpasar.

Ketiga rumusan masalah tersebut akan ditelusuri dengan 2 teori diantaranya teori belajar konstruktivistik yang dikembangkan oleh Jean Piaget dan teori koneksionisme Thorndike. Menurut Jean Piaget dalam Pohan (2019: 211), pengetahuan iu akan bermakna manakala di cari dan ditemukan sendiri oleh siswa. Setiap individu berusaha dan mampu mengembangkan pengetahuaanya sendiri melalui skema yang ada dalam struktur koginitifnya. Skema itu secara terus menerus diperbarui dan diubah melalui proses asimilasi dan akomodasi. Dengan demikian, tugas guru adalah mendorong siswa untuk mengembangkan skema yang terbentuk melalui proses asimilasi dan akomodasi itu. Teori inilah yang dipakai di dalam membedah rumusan masalah pertama dan kedua. Teori yang kedua adalah teori koneksionisme oleh Thorndike, ia menyimpulkan bahwa pembelajarn erat kaitannya dengan stimulus dan respon. Ini terdapat di dalam Pohan (2017:200), disebutkan temuan Thorndike yaitu dorongan yang muncul setelah suatu tingkah laku berpengaruh terhadap tingkah laku berikutnya. Ia percaya bahwa kesiapan peserta didik tergantung pada stimulus yang diberikan oleh pendidik sehingga, siswa dalam hal ini dapat memberikan respon sesuai dengan stimulus yang diberikan. Teori ini akan membedah rumusan masalah yang ketiga.

Metode yang digunakan untuk menemukan temuan dalam artikel ini adalah metode kualitatif dengan jenis penyusunan studi kasus. Metode kualitatif menurut 


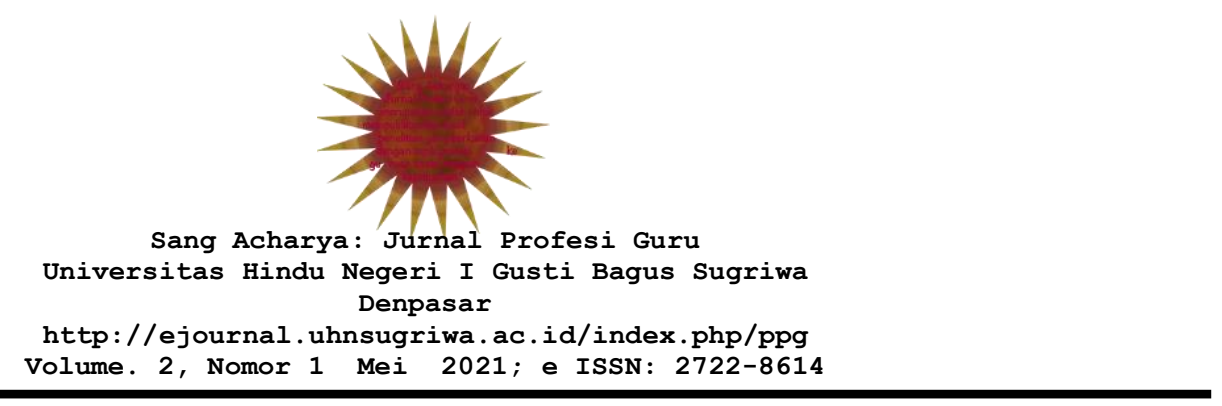

Sugiyono (2020: 9-10) adalah metode penyusunan yang berlandaskan pada filsafat post positivism atau enterpretatif, digunakan untuk meneliti pada kondisi obyek yang alamiah, di mana penyusun adalah sebagai instrument kunci, teknik pengumpulan data trianggulasi (gabungan observasi, wawancara, dokumentasi), data yang diperoleh cenderung data kualtitatif, analisis data bersifat induktif atau kualitatif, dan hasil penyusunan kualitatif bersifat untuk memahami makna, memahami keunikan, mengkontruksi fenomena, dan menemukan hipotesis. Sumber data primer adalah hasil wawancara guru dan siswa. Sumber data sekunder dalam penyusunan ini adalah pustaka berupa buku dan peraturan pemerintah yang dijadikan acuan dalam mengkaji penyusunan ini.

Penentuan informan menggunakan teknik purposive yaitu dipilih dengan pertimbangan tertentu dari penyusun. Teknik ini membuat penyusun harus menentukan sampel dalam menentukan informan. Dipilihlah teknik purposive sampling, dikarenakan yang merupakan teknik pengambilan sampel data dengan pertimbangan tertentu. Sampel yang digunakan adalah non probability sampling, menurut Sugiyono (2020: 95), adalah teknik pengambilan sampel yang tidak memberi peluang atau kesempatan yang sama bagi setiap unsur yang dipilih menjadi sampel.

Penyusun menggunakan instrument, penyusun sendiri sebagai human instrument, berfungsi menetapkan fokus penyusunan, memilih informan sebagai sumber data, melakukan pengumpulan data, menilai kualitas data, analisis data, menafsirkan data, dan membuat keimpulan atas temuannya. Adapun instrument lainnya yang dipergunakan oleh penyusun diantaranya daftar observasi, daftar wawancara secara garis besar, dokumentasi menggunakan handphone, dan alat tulis. Penyusunan ini menggunakan teknik pengumpulan data triangulasi yang artinya mengumpulkan data melalui berbagai teknik pengumpulan data diantarnya observasi, wawancara, dan dokumen. Observasi yang dipergunakan adalah observasi partisipasi aktif dalam Sugiyono (2020:106) observasi ini melibatkan penyusun dalam kegiatan sehari-hari objek yang akan diteliti, dan ikut di dalam melakukan apa yang dilakukan oleh narasumber. Teknik Wawancara yang digunakan adalah wawancara tak berstruktur seperti yang dikemukakan oleh sugiyo (2020: 116), pedoman wawancara ini hanya dibuat secara garis besar saja, dan penyusun ingin mendapatkan data yang lebih mendalam. Teknik analisis data yang digunakan dalam penyusunan ini adalah analisis data model Miles dan Huberman. Seperti yang dikemukakan oleh kedua tokoh itu dalam Sugiyono (2020: 132) aktivitas dalam analisis data kualutatif dilakukan secara interaktif berlangsung secara terus menerus sampai tuntas, sehingga datanya sudah jenuh. Aktivitasnya adalah data reduction, data display, dan conclusion

\section{II.PEMBAHASAN}

\subsection{Alasan penggunaan Strategi Pembelajaran Inkuiri pada Pembelajaran Daring Pendidikan Agama Hindu dan Budi Pekerti Kelas X SMA Negeri 2 Denpasar}

Alasan utama diterapkannya strategi pembelajaran ini adalah guru hanya ingin menjalankan swadharma sebagai guru pengajian. Ia selalu memegang prinsip 


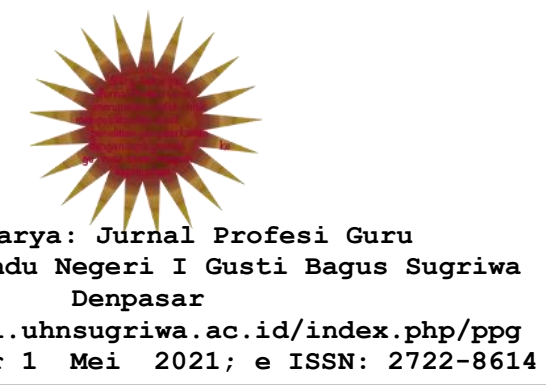

tersebut, tidak hanya pada daring tapi juga kesehariannya mengajar. Dikarenakan etos kerja dan semangatnya yang tinggi untuk mengimplementasikan pembelajaran Agama Hindu dan Budi Pekerti menjadi efektif, menyenangkan, dan aktif. Maka selain mengikuti mengikuti anjuran dari pemerintah berdasarkan surat edaran disdikpora provinsi bali yang sudah dibahas pada pendahuluan, guru juga merasa dalam pembelajaran jarak jauh ini bisa membangun dua komunikasi yang nota bene jarang dilaksanakan pada pembelajaran konvensional seperti tatap muka yaitu komunikasi dengan media learning management system dan terpusat kepada pendidik. Jika dianalisa, jenis komunikasi ini senada dengan komunikasi yang dibangun pada $e$ learning yaitu synchronous dan asynchronous. Komunikasi synchronous menurut Wahyuningsih dan Makmur (2017: 26-27) yaitu komunikasi yang lebih banyak digunakan dalam kegiatan berdiskusi, sehingga dapat mendorong kelancaran berbahasa dari peserta didik. Peran pedidik di dalam komunikasi ini yaitu memberikan bimbingan, dan dukungan secara silmutan kepada peserta didik. Sedangkan, komunikasi asynchronous digunakan untuk mencapai tujuan belajar secara individu, dan cocok digunakan dalam diskusi yang lebih mendalam atau kompleks, dan dapat meningkatkan pemrosesan informasi dalam diri peserta didik.

Guru Agama Hindu kelas X membuktikannya dengan melaksanakan dua jenis komunikasi tersebut di dalam pembelajaran daring yaitu komunikasi synchronous dilakukan dengan alat komunikasi berupa video conference salah satunya adalah penggunaan zoom dan google meet, instant messaging dan chatting yaitu what's ap group, dan komunikasi asynchronous, yang dilakukan dengan cara menggunakan google classroom sebagai wadah bertukar informasi, pemberian tugas, dan diskusi. Adanya komunikasi inilah, yang mendorong guru memilih melaksanakan strategi pembelajaran inkuiri sebagai strategi di dalam proses belajar mengajar. Ini dikarenakan strategi Pembelajaran Inkuiri menurutnya adalah kegiatan pembelajaran yang menekankan pada proses berpikir secara kritis dan analitis untuk mencari, menemukan, dan mengaktifkan kemampuan kognitif siswa, dan tak terkecuali mengintegrasikannya ke dalam sikap dan spiritual. Hal ini senada dengan pendapat dari Seif (1979) dalam Ngalimun (2017: 90) yang mengatakan bahwa Inkuiri berarti mengetahui bagaimana menemukan sesuatu dan bagaimana mengetahui cara untuk memecahkan masalah. Menginkuiri tentang sesuatu berarti mencari informasi, memiliki rasa ingin tahu, menanyakan pertanyaan, menyelidiki, dan mengetahui ketrampilan yang akan membantunya memecahkan masalah.

Jika dikaji dan dianalisa berdasarkan teori konstruktivisme oleh Jean Piaget, strategi ini merupakan rekontruksi dari teori tersebut. Dipaparkan dalam Pohan (2019:211), temuan Pigaet menyatakan bahwa siswa harus aktif mempelajari, mendalami dan mentranformasi informasi, agar informasi dapat dikembangkan oleh siswa menjadi pengetahuan. Ini bertujuan untuk membantu siswa mengontruksi pengetahuan, menggeneralisasikan pengetahuan, dan mengaplikasikan pengetahuan, diantaranya menggunakan pembelajaran inkuiri sebagai implementasinya. Hal ini senada dengan prinsip pembelajaran strategi inkuiri yang diuraikan oleh Raka (2014:26-27) yaitu : 


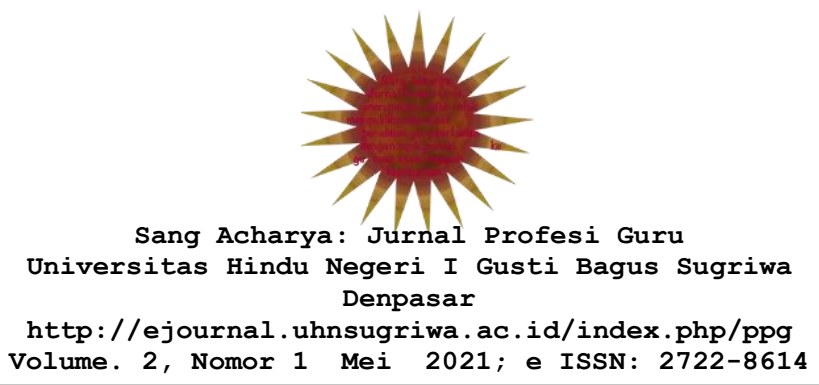

1. Berorientasi pada Pengembangan Intelektual

Tujuan utama dari strategi inkuiri adalah pengembangan kemampuan berpikir. Strategi ini berorientasi kepada hasil belajar, juga berorientasi pada proses belajar.

2. Prinsip Interaksi

Proses pembelajaran adalah proses interaksi, baik interaksi antara siswa maupun interaksi siswa dengan guru, bahkan interaksi siswa dengan lingkungan. Guru perlu mengarahkan agar siswa bisa mengembangkan kemampuan berpikirnya melalui interaksi mereka.

3. Prinsip Bertanya

Peran guru disini sebagai penanya, sebab kemampuan siswa untuk menjawab setiap pertanyaan pada dasarnya sudah merupakan sebagian dari proses berpikir.

4. Prinsip Belajar untuk berpikir

Belajar bukan hanya mengingat sejumlah fakta, akan tetapi belajar adalah proses berpikir (learning how to think), yakni proses mengembangkan potensi seluruh otak, baik otak kiri dan otak kanan.

5. Prinsip Keterbukaan

Belajar adalah suatu proses mencoba berbagai kemungkinan. Segala sesuatu mungkin saja terjadi. Oleh sebab itu, anak perlu diberikan kebebasan untuk mencoba sesuai dengan perkembangan kemampuan logika dan nalarnya. Pembelajaran yang bermakna adalah pembelajaran yang menyediakan berbagai kemungkinan sebagai hipotesis yang harus dibuktikan kebenarannya. Tugas guru adalah menyediakan ruang untuk memberikan kesempatan kepada siswa mengembangkan hipotesis dan secara terbuka membuktikan kebenaran hipotesis yang diajukan.

Menurut Pendidik, strategi ini juga dirasa meramu 4C pada pembelajaran abad 21 yaitu communication, collaboration, critical thingking, dan creative. Dikarenakan dalam proses penerapannya menekankan pada pemikiran kritis dan daya cipta creative yang dilakukan oleh peserta didik. Outputnya, peserta didik diajak untuk berdiskusi dengan pemikiran kritisnya, contohnya dalam kasus membedah nilai yajna yang terdapat di dalam tujuh kanda dalam Ramayana. Daya kreativitas juga muncul diantaranya mengkreasikan tugas video pemahaman materi upaweda. Konsep yang dipaparkan olehnya senada dengan ciri utama strategi pembelajaran inkuiri menurut Raka (2014:24) yaitu:

1. Strategi inkuiri menekankan kepada aktivitas siswa secara maksimal untuk mencari dan menemukan, artinya strategi inkuri menempatkan siswa sebagai subjek belajar. Dalam proses pembelajaran, siswa tidak hanya berperan sebagai penerima pelajaran melalui penjelasan guru secara verbal, tetapi mereka berperan untuk menemukan diri sendiri inti dari materi pelajaran itu sendiri.

2. Seluruh aktivitas yang dilakukan siswa diarahkan untuk mencari dan menemukan jawaban sendiri dari sesuatu yang dipertanyakan, sehingga diharapkan dapat menumbuhkan sikap percaya diri. Dengan demikian strategi pembelajaran inkuiri menempatkan guru bukan sebagai sumber belajar, akan tetapi sebagai fasilitator dan motivator belajar siswa. 


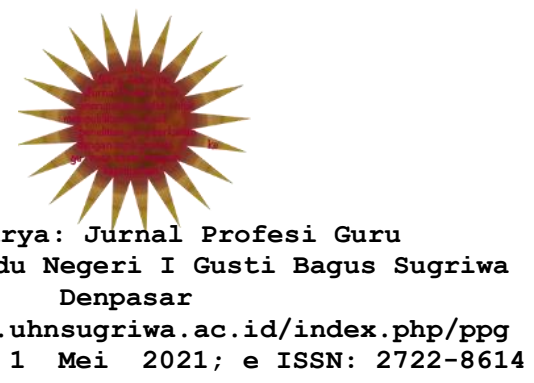

3. Tujuan dari penggunaan strategi pembelajaran inkuiri adalah mengembangkan kemampuan berpikir secara sistematis, logis, dan kritis. Dengan demikian, dalam strategi pembelajaran inkuiri siswa tak hanya dituntut agar menguasai materi pelajaran, akan tetapi bagaimana mereka dapat menggunakan potensi yang dimilikinya. Manusia yang hanya menguasai pelajaran belum tentu dapat mengembangkan kemampuan berpikir secara optimal, namun sebaliknya, siswa akan dapat mengembangkan kemampuan berpikirnya manakala ia bisa menguasai materi pelajaran.

\subsection{Penerapan Strategi Pembelajaran Inkuiri pada Pembelajaran Daring Pendidikan Agama Hindu dan Budi Pekerti Kelas X SMA Negeri 2 Denpasar}

Jean Piaget dengan temuannya konstruktivistik mengungkapkan dalam Pohan (2019:211) esensinya siswa harus bisa menemukan dan mensrtranformasi informasi agar bisa menjadi penngetahuan siswa itu sendiri. Dalam proses transformasi itu, siswa mengecek keabsahan data sesuai denga relevansi yang terdapat di dalam informasi tersebut. Siswa perlu diberikan kesempatan menemukan ide-ide, mengasimiliasi, dan mengaplikasikannya dalam bentuk pengetahuan. Berdasarkan sudut pandang temuan jean piaget tersebut, maka pembelajaran berbasis temuan ditekankan di dalam merekontruksi pemikirannya sebagai pengetahuan yang baru, sehingga muncul pemikiran kritis dan semangat membangun struktur yang lebih fleksibel, nyata, dan berkorelasi dengan kehidupan nyata. Terkait hal tersebut maka fungsi dan peranan guru di dalam pembelajaran inkuiri menjadi komponen utama selain siswa sebagai pelaksana pengetahuan.

Peranan Guru di dalam pembelajaran inkuiri menurut Ngalimun (2017:102) adalah menciptakan lingkungan yang dapat menciptakan masalah-masalah yang memadai dan menstimulasi pertanyaan-pertanyaan dan meneliti di antara siswa itu sendiri, daripada menjadi sumber utama informasi bagi siswanya. Guru dapat mengarahkan siswanya dalam menemukan informasi bagi mereka sendiri dan mengarahkan pertanyaan-pertanyaan yang memadai atas suatu masalah.Peranan ini juga harus dijaga oleh peserta didik, agar guru dapat mengarahkan siswa sebagaimana mestinya. Seperti yang dikemukakan oleh Sandika (2011:56) Guru diyakini sebagai perealisasian Brahman di dalam menjalankan swadharmanya menebarkan pengetahuan kepada sisya atau brahmcarya. Kewajiban brahmcarya adalah menerapkan disiplin guru bhakti, yakni sikap hormat seorang siswa terhadap acharya atau gurunya. Maka di dalam menjalankan perannannya, siswa juga musti menjaga kedisiplinan diri, dikarenakan ini adalah faktor utama di dalam melaksanakan proses pelaksanaan strategi ini sehingga berjalan dengan baik dan lancar. Secara umum pelaksanaan pembelajaran menggunakan startegi ini diungkapkan oleh Raka (2014:28-30) yaitu

1. Orientasi

Langkah orientasi atau pengenalan dapat dijabarkan sebagi berikut 


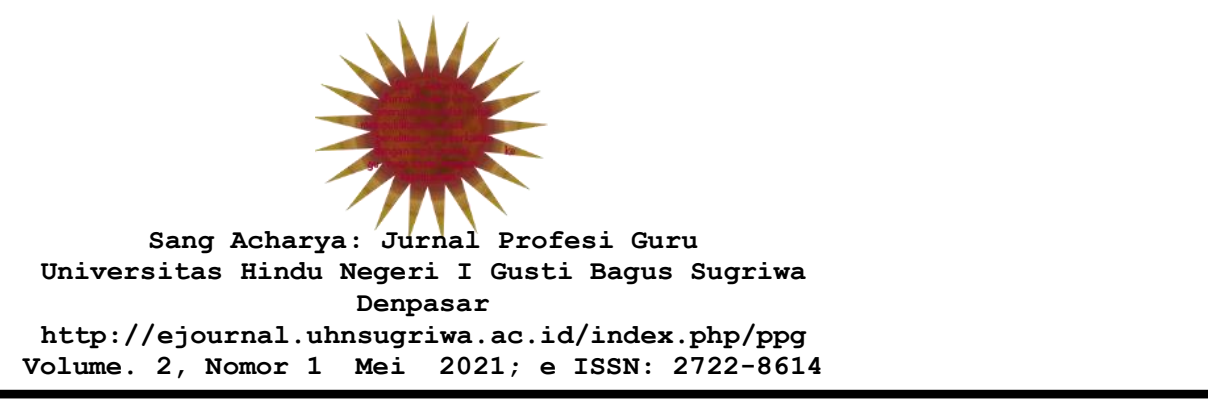

- Menjelaskan topic, tujuan, dan hasil belajar yang diharapkan dapat dicapai oleh siswa.

- Menjelaskan pokok-pokok kegiatan yang harus dilakukan oleh siswa untuk mencapai tujuan

- Menjelaskan pentingnya topik dan kegiatan belajar.

2. Merumuskan masalah

Menghantarkan siswa pada persoalan yang mengandung teka teki. Persoalan yang disajikan adalah persoalan yang telah mengandung jawaban terstruktur.

3. Mengajukan hipotesis

Mengajukan pertanyaan dan mendorong anak untuk dapat merumuskan jawaban sementara dari pertanyaan tersebut yang bersifat rasional dan logis.Ini akan dipengaruhi oleh kedalaman wawasan berpikir dan keluasan pengalaman.

4. Mengumpulkan data

Mengumpulkan data adalah aktivitas menjaring informasi yang dibutuhkan untuk menguji hipotesis yang diajukan.Inilai proses pengembangan intelektual.

5. Menguji hipotesis

Proses menentukan jawaban yang dianggap diterima sesuai dengan data atau informasi yang diperoleh berdasarkan pengumpulan data. Ini fungsinya untuk mencari tingkat keyakinan siswa.

6. Merumuskan kesiumpulan

Merumuskan dan mendeskripsiskan temuan yang diperoleh berdasarkan hasil hipotesis. Guru mampu menarik kesimpulan dengan temuan yang ada.

Pemaparan dari pendapat Raka (2014), di atas selaras dengan tahapan-tahapan yang dilaksanakan oleh Guru Agama Hindu kelas X. Sebelumya, perlu diketahui bahwa jadwal pembelajaran Agama Hindu dan Budi Pekerti sangatlah singkat yaitu satu jam pada Hari Senin, 08.00-09.00 WITA, untuk sebelas kelas yang merupakan kelas XIPA dan kelas XIPS . Ini dikarenakan penyesuaian pada jam daring yang diberlakukan oleh Sekolah Menengah Atas Negeri 2 Denpasar. Maka dari itu, guru dalam hal ini mengatur jadwal kembali dan bergiliran membentuk forum diskusi pada google classroom dan berdiskusi di zoom atau google meet, dengan waktu satu jam untuk membagi siswa menjadi grup diskusi per kelas. Secara umum pelaksanaannya, kelas XIPA 1, XIPA 2, XIPA 3, dan XIPA 4 mendapatkan giliran pertama berdiskusi, untuk kelas selanjutnya XIPA 5, XPA 6, XIPA 7, XIPS 1, XIPS 2, XIPS 3, dan XIPS 4, dilaksanakan dengan mencari, menghimpun, dan mengeksplor pengetahuan sendirinya berdasarkan referensi, dan diskusi bersama orang tua, atau anggota keluarga lainnya mengenai persoalan yang diungkapkan di dalam video pembelajaran. Bergantian terus, sesuai dengan jadwal hari senin minggu depannnya digilir untuk mendapatkan forum diskusi di classroom.

Secara eksplisit, penyusun mengambil contoh pelaksanaan strategi ini pada materi Sad Darsana dengan kompetensi dasar Menjelaskan Menjelaskan ajaran Dharsana dalam agama Hindu dengan indicator: (1) Menjabarkan tetang pengertian Dharsana (2) Menjabarkan pengertian bagian-bagian Sad Darsana Tahapan yang dilaksanakan oleh guru adalah sebagai berikut: 
1. Tahap Perencaaan

Guru mempersiapan rencana pelaksanaan pembelajaran, dan sumber belajar, media, dan membuat video pembelajaran bentuk-bentuk pelaksaan yajna dalam kehidupan sehari-hari kemudian diupload di kanal youtube PDD Agama Hindu dan Budi Pekerti. Kemudian mempersiapkan link absen google formulir yang diupload pada google classroom

2. Tahapan Pelaksanaan

Tahap pelaksanaan strategi yang dilaksanakan oleh Guru Agama Hindu kelas X selaras dengan pendapat yang dikemukakan Raka (2014) diantaranya

a. Orientasi

Video pembelajaran yang diupload telah dipersiapkan seminggu sebelumnya dengan content yang terstruktur diantaranya berisi intro, isi, dan outro, lebih lengkapnya diuraikan berikut ini:

- salam panganjali Om Swastyastu, dilanjutkan dengan intro menyapa siswa,

- kemudian doa belajar Om Pavakannah Sarasvati Vajbhir Vajinivati Yajnam Vastu Dhiyawasuh. Mantram ini memilki arti agar senantiasa diberikan pencerahan dan inspirasi oleh Ida Sang Hyang Aji Saraswati di dalam menjalankan swadharmanya sebagai siswa. Berdasarkan penuturannya mantram ini diambil dari Rg. Veda 1.3.10 dari Dainika Upasana yang dihimpun oleh Dr. Titib (2000)

- Dilanjutkan denngan mengemukakan tujuan dari mempelajari Nyaya Darsana, salah satunya penggunaan metode Catur Pramana. Dipaparkan sedikit mengenai konsep catur pramana: Pratyaksa (pengamatan langsung), Anumana (penyimpulan), Upamana (perbandingan), Sabda (klarifikasi)

b. Merumuskan Masalah

Dilanjutkan pada video tersebut mengenai salah satu kasus rumah tangga diantaranya mengamati masalah problema remaja, yang mengalami keterpurukan dan kehilangan jati diri, akibat dipaksa oleh orang tuanya kuliah di jurusan yang tidak sesuai dengan kehendaknya. Akibatnya, ia mulai melakukan tindakan destruktif dan maraca, Sampai akhirnya, ia ditangani oleh psikolog.

c. Mengajukan Hipotesis

Beranjak dari video, guru sebelumnya, membuat pengumuman pada google classroom pada forum diskusi, untuk menghantarkannya, guru memantik pertanyaan-pertanyaan yang mengembangkan wacana diskusi. Selain pada forum diskusi google classroom guru juga mengajukan pertanyaan pada kesempatan diskusi tatap muka virtual pada zoom dan google meet.

d. Mengumpulkan data dan Menguji Hipotesis

Siswa kemudian mengumpulkan data dari sumber terkait misalkan berselancar di google, buku paket, buku lembar penunjang kerja siswa, buku agama hindu, dan buku-buku lainnya yang relevan dengan pertanyaan yang disampaikan oleh Guru. Guru juga menguji informasi yang didapatkan oleh siswa, sehinga siswa kembali mengecek keabsahan data yang ia peroleh dari sumber bersangkutan. Data yang dikumpulkan berupa pengamatan siswa 


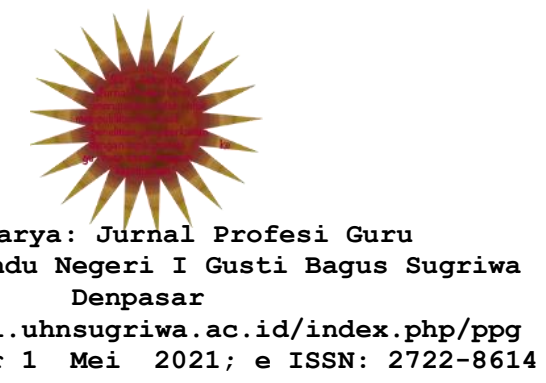

terhadap permasalahan remaja yang telah diungkapkan pada video, kemudian mengujinya dengan catur pramana. Alih perspektif antara pratyaksa, anumana, upamana, dan sabda.

e. Menyimpulkan

Siswa dan guru kemudian sama-sama menyimpulkan materi yang disampaikan sebagai pesan akhir pembelajaran, sehingga dalam hal ini materi yang disampaikan telah memiliki arti yang mendalam dan luas, serta sangat komprehensif.

Pelaksanaan strategi ini juga dirasa cukup memberikan ruang bagi peserta didik di dalam menciptakan pembelajaran yang aktif dan menyenangkan. Namun memang ada saja hambatan yang dilalui oleh pendidik maupun peserta didik diantaranya hambatan sinyal, kuota, dan kondisi media seperti handphone dan laptop yang kondisinya tidak memadai memakai aplikasi google classroom dan google meet. Bagi siswa yang mengalami kendala demikian, maka guru memberikan pembinaan intensif kepada siswa tersebut melalui what's app personal, sehingga siswa tidak ketinggalan pembelajaran. Misalnya memberikan arahan secara khusus kepada siswa yang terkendala, dengan mengeshare link youtube, dan memberikan tugas pengganti yang mewajibkan siswa mengeksplore dan melaporkannya pada guru yang bersangkutan.

\subsection{Implikasi Strategi Pembelajaran Inkuiri pada Pembelajaran Daring}

Thorndike dengan teorinya koneksionisme dalam Pohan (2017: 200) percaya bahwa semua pembelajaran dapat dapat ditelusuri dari koneksi yang terbentuk antara dorongan dan jawaban atau respon. Pembelajaran dinilai sebagai sebuah koneksi yang pasti. Sehingga, dalam proses pembelajaran ada tahapan perubahan yang dirasakan oleh peserta didik, setelah melaksanakan pelatihan dan adanya dorongan dari pendidik. Jika dilihat dari perspektif Thorndike maka, peserta didik diibaratkan sebagai komponen integral yang menandakan keberhasilan pendidik mengajar. Hukum kesiapan sebagai principal koneksionisme membuktikan bahwa peserta didik akan senantiasa siap menghadapi dunia pendidikan, ketika sang guru melaksanakan metode dan strategi pelatihan dan pengajaran yang tepat.

Dilihat pada Warnita (2020) jurnal yang berjudul "Mengoptimalkan Penggunaan Model Inquiri Learning Upaya Meningkatkan Aktivitas Dan Hasil Belajar Pendidikan Agama Hindu Peserta Didik Kelas IV Semester Satu Tahun Pelajaran 2019/2020 Di SD Negeri 34 Cakranegara", menghasilkan temuan yaitu penerapan pendekatan Saintifik model Pembelajaran Inquiri sangat efektif upaya untuk meningkatkan aktivitas dan hasil belajar Pendidikan Agama Hindu peserta didik kelas IV Semester Satu tahun pelajaran 2019/2020 di SD Negeri 34 Cakranegara. Fakta telah menunjukkan perolehan rata-rata skor aktivitas belajar peserta didik pada siklus I ke siklus II sudah melampaui Indikator keberhasilan yang ditetapkan. Penyusunan dinyatakan "berhasil" dan dihentikan pada siklus II. Penyusunan tersebut membuktikan secara aspek kognitif yang dinilai dari ketuntasan siswa di dalam meraih Kriteria Ketuntasan Minimal atau KKM dibanding sebelum dilaksanakannya Model 


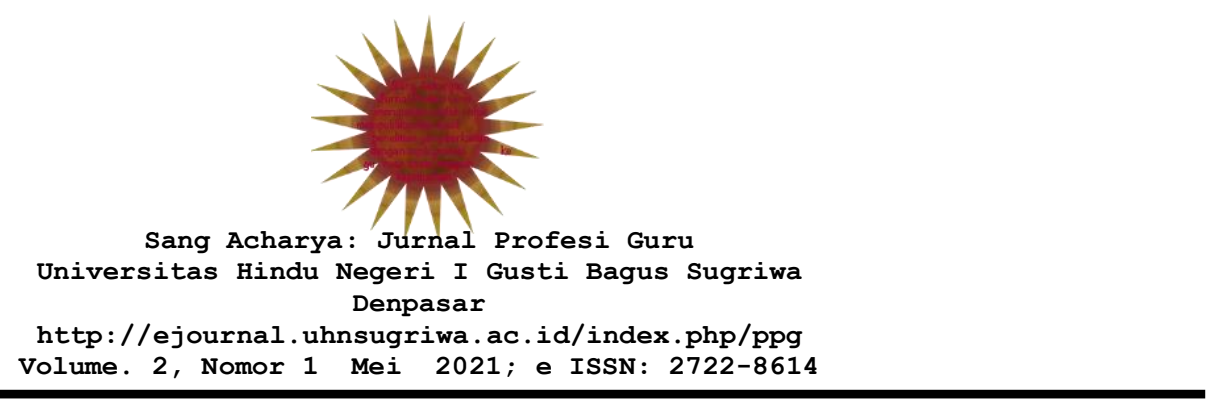

Pembelajaran Inkuiri. Objek penyusunan adalah siswa sekolah dasar, sedangkan dalam pembahasan kali ini, menukik pada siswa kelas XSMA Negeri 2 Denpasar.

Salah satu siswa kelas X SMA Negeri 2 Denpasar, Ida Ayu Mutiara Pradnya Sinta, Kelas X IPA 7, setelah mengobservasi what's app tanggal 25 Januari 2021 pukul 11.00 wita mengatakan "selama ini ibu guru telah memberikan pembelajaran yang cukup menyenangkan, ditambah video pembelajaran yang menarik, dan rasa ingin tahu saya semakin bertambah. Saya merasa lebih kritis melihat fenomena di rumah, di lingkungan sekitar terkait dengan pelaksanaan Agama Hindu, materi yang saya sukai dan menurut saya sangat challenging adalah nyaya darsana dan catur asrama.Ibu guru juga memberi ruang kretaifitas pada saya dan teman-teman untuk membuat video pembelajaran bhakti kepada catur guru sebagai bagian swadharma Brahmacari. Tetapi terkadang akibat gangguan sinyal, kuota habis,dan wifi saya terkendala mengikuti pembelajaran ini, ditambah video ibu yang durasinya cukup panjang.", ujarnya. Berbeda halnya yang diungkapkan oleh Ayu Sri Krisna Murti kelas X IPS 3, diwawancara via what's app tanggal 22 Februari 2021 mengatakan "Bu Sinta perhatian dengan muridnya, saya merasa senang ketika ibu Sinta mengajar, karena ketika bu sinta selalu memberikan ruang bagi kita untuk bertanya, menjawab, diskusi, dan ketika di google meet terasa lebih aktif. Bahkan tak jarang ibu guru memberikan pertanyaan-pertanyaan ditambah referensi yang harus dicantumkan ketika menjawab pertanyaan tersebut, sehingga serasa kita harus mengutamakan tanggung jawab akan jawaban dari pertanyaan tersebut." Beberapa siswa juga mengutarakan hal yang sama, setelah diajarkan menggunakan strategi pembelajaran inkuiri.

Prinsipnya, guru juga tidak hanya mengajarkan aspek kognitif pada siswanya, tetapi juga menekankankan 3 aspek lainnya agar pembelajaran menjadi terintegrasi satu sama lainnya. Adanya doa belajar sebagai wujud penanaman sikap spiritual, dan mengingatkan siswa akan Sraddha yaitu percaya dengan adanya Brahman. Sikap sosial yang ditekankan oleh guru untuk senantiasa bertanggungjawab dan disiplin mempertanggungjawab tugas agama hindu yang diberikan, termasuk di dalam proses pembelajaran misalnya pada saat tatap muka online menggunakan google meet, siswa harus mengenakan pakaian rapi, dan harus tepat waktu, serta tertib walaupun berada di rumah. Aspek ketrampilan ditekankan ketika guru memberikan tugas video sebagai feed back pemahaman mereka terhadap materi yang diberikan, sebagai contohnya di dalam materi Catur Asrama (Brahmacari). Siswa diminta membuat video berdurasi 12 menit menggunakan tatanan yang sopan dan santun, mempraktikkan bhakti terhadap catur guru di rumah saja, serta penyampaian materi menggunakan bahasa mereka sendiri. Beberapa siswa mengaku adanya perubahan terhadap sikap mereka, termasuk respect terhadap agama hindu yang merupakan keyakinan mereka sendiri. Walaupun selama daring, diberikan batasan waktu yang cukup tak memadai, sehingga terkadang terasa kurang dalam hal belajar Agama Hindu. Guru juga mengakui bahwa dengan menerapkan strategi ini, tentu tidak semulus hasil yang diharapkan, masih ada siswa yang melanggar aturan, dan tidak disiplin. Adapula yang hanya sekadar menjawab tanpa referensi, dan seperti tidak konsen di dalam proses pembelajaran. Tetapi, hal itu tidak membuat guru menyerah begitu saja akan keadaan tersebut, walaupun daring guru tetap saja memberikan bimbingan dan binaan personal kepada siswa yang 


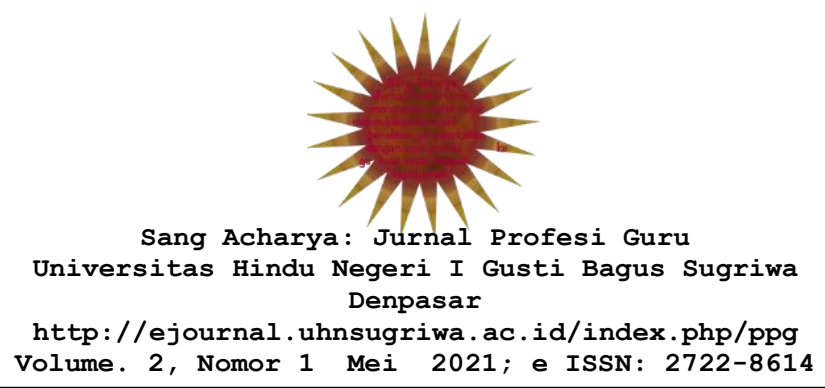

bermasalah, agar ada perubahan ke depannya. Guru juga mengakui masih ada 2 sampai 3 peserta didik per kelasnya yang tidak merespon panggilan serta what's app dari pendidik walaupun telah diberikan notice, bimbingan, bahkan pembinaan. Guru dalam hal ini saling berkordinasi dengan guru wali kelas dan guru BK untuk samasama memberikan pembinaan terhadap peserta didik tersebut.

Didapati sebagai pengalaman empirik baru yang dialami oleh siswa. Awalnya siswa bingung akan pencatuman referensi, dan mencari informasi dengan bantuan google, yang ada relevansinya terhadap materi yang diajarkan. Tetapi, dengan pola latihan yang terbentuk dengan adanya strategi pembelajaran inkuiri ini, siswa menjadi terbiasa untuk mencari, mengamati, menguji pemahaman sendiri di dalam proses belajarnya. Maka dapat disimpulkan implikasi yang dirasakan oleh guru maupun siswa ada yang bersifat positif yaitu adanya perubahan terhadap afektif, kognitif, dan psikomotor. Tetapi, ada juga implikasi yang masih stagnan terhadap beberapa peserta didik, yang mengalami masalah dalam belajar, baik dikarenakan faktor teknik ataupun non teknis.

\section{Penutup}

\subsection{Simpulan}

Strategi pembelajaran inkuiri yang menekankan pada keaktfian siswa mengkonstruski pengetahuan diterapkan di dalam pembelajaran Agama Hindu dan Budi Pekerti khususnya kelas X SMA Negeri 2 Denpasar semester genap tahun pelajaran 2020/2021, alasan diterapkannya, dikarenakan guru memiliki (1) semangat, etos kerja, serta concern mencari strategi yang tepat guna digunakan selama $e$ learning; (2) komunikasi dengan media learning management system yang disebut synchronous dan terpusat kepada pendidik atau asynchronous; (3) strategi ini juga dirasa meramu 4C pada pembelajaran abad 21 yaitu communication, collaboration, critical thingking, dan creative. Penerapan strategi ini, dibagi menjadi dua tahapan yaitu (1) perencanaan, (2) pelatihan dengan tahapan orientasi, merumuskan masalah, membangun hipotesi, menguji hipotesis, dan menarik kesimpulan. Kendala yang dihadapi guru dan peserta didik beragam mulai dari masalah teknis seperti signal dan kuota. Implikasi dari strategi ini, bisa dilihat bahwa peserta didik merasa pemahaman secara kogintif mulai bertambah, dan tak melupakan unsur afektif, serta psikomotor.

\section{DAFTAR PUSTAKA}

Maswan dan Muslimin. 2017. Teknologi Pendidikan Penerapan Pembelajaran yang Sistematis. Yogyakarta: Pustaka Belajar

Ngalimun. 2017. Strategi Pembelajaran dilengkapi 65 Model Pembelajaran. Yogyakarta: Parama Ilmu 
Sang Acharya: Jurnal Profesi Guru

Universitas Hindu Negeri I Gusti Bagus Sugriwa

Denpasar

http: //ejournal.uhnsugriwa.ac.id/index.php/ppg

Volume. 2, Nomor 1 Mei 2021; e ISSN: 2722-8614

Raka. 2014. Diktat Strategi Pembelajaran. Denpasar: UNHI

Sandika. 2011. Pendidikan Menurut Weda Sadhana Spiritual bagi Generasi Muda. Surabaya: Paramitha

Pohan. 2019. Filsafat Pendidikan : Teori Klasik hingga Post Moderenisme dan Problematikanya di Indonesia. Jakarta: Rajawali Press

Sugiyono. 2020. Metode Penyusunan Kualitatif. Bandung: Alfabeta

Wahyuningsih dan Makmur. 2017. E-Learning Teori dan Aplikasi. Bandung: Informatika

Warnita. 2020. Mengoptimalkan Penggunaan Model Inquiri Learning Upaya Meningkatkan Aktivitas Dan Hasil Belajar Pendidikan Agama Hindu Peserta Didik Kelas IV Semester Satu Tahun Pelajaran 2019/2020 Di SD Negeri 34 Cakranegara terdapat di dalam Jurnal Ilmu Sosial dan Pendidikan http://ejournal.mandalanursa.org/index.php/JISIP/indeXVol. 4. No. 2 Maret 2020

https://disdikpora.baliprov.go.id/wp-content/uploads/2020/03/SE-51-SATGAS-

COVID-KEBIJAKAN-PENDIDIKAN-DI-PROVINSI-BALI.pdf diakses pada tanggal 18 Mei 2021 